Article

\title{
Social Capital on Social Media-Concepts, Measurement Techniques and Trends in Operationalization
}

\author{
Flora Poecze ${ }^{1}$ and Christine Strauss ${ }^{2, *(D)}$ \\ 1 Institute of Information Systems, Vienna University of Technology, 1040 Vienna, Austria; \\ flora.poecze@tuwien.ac.at \\ 2 Department of Marketing and International Business, University of Vienna, 1010 Vienna, Austria \\ * Correspondence: christine.strauss@univie.ac.at
}

Received: 27 September 2020; Accepted: 2 November 2020; Published: 4 November 2020

check for updates

\begin{abstract}
The introduction of the Web 2.0 era and the associated emergence of social media platforms opened an interdisciplinary research domain, wherein a growing number of studies are focusing on the interrelationship of social media usage and perceived individual social capital. The primary aim of the present study is to introduce the existing measurement techniques of social capital in this domain, explore trends, and offer promising directions and implications for future research. Applying the method of a scoping review, a set of 80 systematically identified scientific publications were analyzed, categorized, grouped and discussed. Focus was placed on the employed viewpoints and measurement techniques necessary to tap into the possible consistencies and/or heterogeneity in this domain in terms of operationalization. The results reveal that multiple views and measurement techniques are present in this research area, which might raise a challenge in future synthesis approaches, especially in the case of future meta-analytical contributions.
\end{abstract}

Keywords: social capital; social media; operationalization; measurement; scoping review

\section{Introduction}

The launch of Web 2.0 at the turn of the 21st century enabled a communication revolution. This was followed by the rapid emergence of diverse social media platforms, of which Friendster was one of the first globally known ones; in turn, a growing scientific interest started to characterize the present era [1,2]. This concentrated attention brought up a heterogeneous set of terminological approaches for the novel phenomenon termed "social media" (SM) [3].

Scientific publications in this domain commonly highlight the interactive function of the platforms in question. Furthermore, their services that offer instant communication, extended with possibilities offered as user-generated content (UGC) such as liking, sharing, and commenting. Based on such reasons, one of the most widely used definitions in this area of research is offered by Kaplan and Haenlein (2010), according to whom social media platforms are "internet-based applications that build on the ideological and technological foundations of Web 2.0, and that allow the creation and exchange of user generated content" [4]. VanMeter et al. (2015) stated that such platform is an interactive one, which "allows social actors to create and share in multi-way, immediate and contingent communications" [3]. The core nature of social media platforms is the purpose of enhancement and maintenance of individual user relationships; therefore, SM use can be considered as an investment in social relationships [5]. The exponential user base growth on a plethora of social media platforms has a multitude of individual, underlying reasons, from which this paper will tap into the human drive for social interactions and engagement, and evolutionary phenomena 
(e.g., survival, reproduction), facilitated by cooperation and trust, leading to the perception of an individual's reputation.

The human need to belong is a widely discussed psychological phenomenon [6]. There are empirical suggestions for the influence of this drive on college students' social media use, manifesting in interaction and social engagement [7]. The need for belongingness appeared in Maslow's [8] theory of human motivation, which is manifesting itself on today's social media platforms. Drawing back to the thoughts of Baumeister and Leary (1995), this motivation leads individuals to enhanced efforts to broaden and strengthen their social connections. As discussed in the previous social media literature, belongingness and self-representation [9] are considered among the primary reasons for social media use [10]. Taking into of Lin's (2001) definition, social capital is the "investment in social relations with expected returns in the marketplace" [11]. Under these circumstances, individual social media presence is indeed influenced by the drive for belongingness, paired with expected returns, which, under these circumstances, indicates enhanced social ties and the possibility of leveraging social support [12].

Considering the exponential growth of the global user base and the diversity of social media platforms, which have become part of humanity's everyday lives, the measurement of individual social capital on social media has become a crucial area of investigation. The expected and perceived returns, which characterize this phenomenon make it essential for scientists to empirically examine and quantify their potential impacts on the lives of individuals at a global scale. Therefore, emerging scientific attention has turned to operationalize and validate social capital scales, the evaluation of which can possibly describe this phenomenon in detail.

There are indications, however, that there are possible inconsistencies present regarding the measurement techniques of perceived individual social capital. Williams (2006) pointed out, based on the theories of Putnam (2000), that the bridging and bonding dimensions of the cultural view of social capital are not orthogonal (cf. ibid., pp. 596-597), which can lead to possible measurement discrepancies. Further concerns suggested that the distinction between bridging and bonding social capital is rather ad hoc [13]; therefore, their treatment in such manner can possibly lead to harmful consequences [14]. Additional critics [14] highlighted the issue that Granovetter's seminal works about the implications of weak and strong social ties $[15,16]$, which indicated that weak ones are possibly more important than strong ones, are dominating this research field [17].

In this manner, this investigation aims to scope the presently existing measurement techniques and trends in this research area. No hypotheses were set in this study, reflecting on its exploratory nature. The rest of this article is structured as follows. In the next section, we present a terminological outline of the existing social capital theories. This leads to differentiation regarding online and offline social capital. The birth and theoretical development of this phenomenon is then presented. This includes a discussion of the cultural and multidimensional views of social capital, as subjects of the vast majority of publications operationalizing social capital. The items of measurement are detailed. This is followed by a presentation of the research methodology, aiming to explore past scientific research measuring social capital, paying attention to possible inconsistencies regarding operationalization techniques. The results are presented next, followed by the conclusions, limitations of the present paper, and future research suggestions.

\section{Literature Review}

Social capital terminology has undergone a substantial transformation since its birth. As a possible reason for such diversity, Fine (2010) [18] highlighted that previous research practices applied an appropriate definition matching the particular application in question [19-22]. According to Bourdieu, social capital is the "aggregate of the actual or potential resources which are linked to possession of a durable network of more or less institutionalized relationships of mutual acquaintance and recognition" [23], emphasizing that it is a form of capital, measurable on an individual or group level, characterizing embedded relationships between individuals. Furthermore, Coleman defines social capital as an accumulation of resources stemming from various individual relationships [24]. 
Portes highlighted the importance of the structure of such relationships, wherein the actors of this phenomenon are located [22], while Fukuyama underlined the importance of co-operation among individuals, which promotes social capital [25].

According to Putnam, social capital is social networks associated with the norms of reciprocity, indicating that the phenomenon itself jointly describes these networks and their effects on participating individuals. [26] However, to offer a brief outlook regarding the up to date inconsistencies regarding social capital discussed in detail by Fine [18], the argument of social capital being the cause, the effect, or the process itself, is a matter of present scientific debates as well [27].

The emergence of Web 2.0 brought further developments regarding the theory and parallel development of the applied measurement techniques of social capital, distinguishing between online and offline contexts, with research indicating that the use of the Internet is associated with trust and community involvement enhancement. [28] The impact of the Internet as a surrogate and a supplement of human communication has been discussed widely in scientific research, the focus of which has been e-mail usage [29], or the functions of chat rooms in idea sharing and political participation [30] in the early stages of Internet studies in social capital research.

With the emergence of computer-mediated social networks, the discussion of the associations between social capital and individual tie strength research, investigating both strong and weak ties in an online context based on Granovetter's social tie theories $[15,16]$, opened a new research field. The aim for the development of online social capital became one of the core aspects of empirical research, a milestone of which was the development and validation of the first comprehensive online social capital scale by Williams [27]. To better understand the importance and details of this contribution, it is essential to discuss the most widely discussed, existing views of social capital theory. This is crucial to grasp the context of this scale, which still has one of the most noted impacts in the present, empirical social capital research measured on social media.

The birth of social capital as a scientific phenomenon is unclear [18]. According to Hofer and Aubert (2013), Lyda Hanifan's article from 1916 [31] can be seen as a possible theoretical root [32]. Hanifan's rediscovery during the beginning of the 21st century can be potentially attributed to an article by Putnam and Goss (2002), in which the authors stated that her definition encompassed all of the crucial elements identified ones in contemporary science [33].

The beginning of the 1980s marked its first concentrated attention through the works of French radical sociologist Pierre Bourdieu, joined by American rational choice sociologist James Coleman, who started elaborating on this topic in the late 1980s and early 1990s [34]. Robert Putnam's investigations during the turn of the century [26] took an important scientific step towards, through the definition and conceptualization of bridging and bonding social capital. This based on Granovetter's works on social tie strength $[15,16]$, wherein he proposed that strong social ties (e.g., family or friends) are not valuable for an individual in the process of a new job acquisition. However, weak social ties (i.e., the vast network of acquaintances) are beneficial for the individual in question [15]. Based on Granovetter's seminal works, Putnam (2000) proposed that a person's bridging social capital (i.e., weak social ties) is valuable for the acquisition of previously unknown, new information, while the function of bonding social capital refer to an individual's strongest ties, is the provision of social and emotional support (cf., [35]).

In parallel to the previously described cultural view of social capital $[23,24,26]$, and theorists of the structural view $[3,8,18]$, the turn of the century marked Nahapiet and Goshal's seminal work (1998). This work elaborated on the multidimensional view of social capital, segmenting it into structural (i.e., social interaction ties), relational (i.e., shared language, cultural understanding) and cognitive (i.e., trust, norms, obligations, identification) dimensions [36].

Social capital has been put into relationship analyses with enormously diverse phenomena. Fine (2010) offered several curious examples [18] (e.g., the prevention of deforestation [37], skin color as a factor in marriage prospects [38], or pets as social capital conduits [39]). The most promising research platforms in social capital studies are social media platforms, building upon belongingness as a human 
drive, and social engagement. The shared question of such studies is, whether or not the use of social media affects the individual's perception of the social capital of the self and the perceived social support (see the meta-analysis of Domahidi, 2018 [40]). As a result, the number of papers is growing rapidly, in which the perceived individual social capital is analyzed on social media platforms [41].

The different aspects, viewpoints, and theoretical considerations in terms of social capital raise the question of how these are operationalized for further empirical investigation and evidence. The development of measurement techniques was already urged by Quan-Haase and Wellmann in 2004, who argued for its necessity based on the accelerated emergence of the Internet in parallel to the development of social capital [42]. Following this call, Williams (2006) created the Internet Social Capital Scale (ISCS), consisting of two scales proposed to measure bridging, and bonding social capital, respectively, including 10-10 measurement items, based on Putnam's (2000) conceptualization. [27] These scales were extended and modified [1], wherein the bridging and bonding social capital of Michigan State University (MSU) students was measured. The aim was the analysis of student social capital, the intensity of Facebook use and further control variables. In this article, the authors introduced the definition and measurement of maintained social capital as well, which refers to such prior, high school social connections of students that were later maintained during their time spent in higher education.

The following table aims to introduce the measurement items of the ISCS [27], in comparison to those items that were included in the seminal work of Ellison et al. (2007) (cf. Table 1).

Table 1 illustrates that Ellison et al. (2007) adapted five statements from the ISCS, slightly adjusting the statements to the MSU context, while they operationalized and validated a scale for maintained social capital as well. Therefore, Table 1 presents the five distinct measurement items of this social capital construct as well.

The dichotomous handling of bridging and bonding social capital has raised concerns. As Williams (2006) pointed out, these constructs "are not mutually exclusive, [ ... ], they are oblique rather than orthogonal to one another" [27]. Their treatment as distinctive constructs can result in harmful consequences; therefore, they should be handled as oblique ones [14]. Further critics noted that the distinction between bridging and bonding social capital measurement instruments is rather ad hoc [13]. Additionally, based on the wide recognition of Granovetter (1973), which highlighted the importance of weak social ties, academic research tended to highlight the existence of this phenomenon and sought evidence for its underpinning [17]. This has also generated concerns in recent studies [14].

The development of the measurement constructs in the multidimensional view of social capital followed a different path in operationalization (see [4], pp. 140-157, for a critical summary) from the end of the 1990s until 2006. This marked the year of the publication of the article by Chiu et al. (2006), which created and validated a comprehensive set of items for all three studied social capital dimensions (i.e., structural, relational, cognitive) (Table 2) [43].

The history of measurement development in the multidimensional view of social capital reached a milestone with the seminal work of Chiu et al. (2006), which built upon the work of Tsai and Goshal (1998). The definition of the structural dimension as social interaction ties, the relational one as trustworthiness and trust, and the cognitive one as shared vision (in an enterprise setting) was defined by these authors. They created a standardized betweenness index for the evaluation of social interaction ties, while standardized in-degree, centrality was calculated for the measurement of trust and trustworthiness. The cognitive dimension was measured through two Likert-scale items [44]. 
Table 1. Comparison of measurement items from Williams' Internet Social Capital Scale (ISCS) with measurement items from Ellison et al. (2007). MSU: Michigan State University.

\begin{tabular}{|c|c|c|c|c|}
\hline Online/Offline Bridging SC [27] & Online/Offline Bonding SC [27] & Bridging SC [1] & Bonding SC [1] & Maintained SC [1] \\
\hline $\begin{array}{c}\text { Interacting with people } \\
\text { online/offline makes me interested } \\
\text { in things that happen outside my } \\
\text { town }\end{array}$ & $\begin{array}{l}\text { There are several people online/offline I trust } \\
\text { to help solve my problems }\end{array}$ & I feel I am part of the MSU community & $\begin{array}{l}\text { There are several people at MSU I trust } \\
\text { to solve my problems }\end{array}$ & $\begin{array}{l}\text { I'd be able to find out about events in } \\
\text { another town from a high school } \\
\text { acquaintance living there }\end{array}$ \\
\hline $\begin{array}{l}\text { Interacting with people } \\
\text { online/offline makes me want to try } \\
\text { new things }\end{array}$ & $\begin{array}{c}\text { There is someone online/offline I can turn to } \\
\text { for advice about making very important } \\
\text { decisions }\end{array}$ & I am interested in what goes on at MSU & $\begin{array}{l}\text { If I needed an emergency loan of } \$ 100, \text { I } \\
\text { know someone at MSU I can turn to }\end{array}$ & $\begin{array}{l}\text { If I needed to, I could ask a high school } \\
\text { acquaintance to do a small favor for me }\end{array}$ \\
\hline $\begin{array}{l}\text { Interacting with people } \\
\text { online/offline makes me interested } \\
\text { in what people unlike me are } \\
\text { thinking }\end{array}$ & $\begin{array}{l}\text { There is no one online/offline that I feel } \\
\text { comfortable talking to about intimate } \\
\text { personal problems. (reversed) }\end{array}$ & MSU is a good place to be & $\begin{array}{l}\text { There is someone at MSU I can turn to } \\
\text { for advice about making very } \\
\text { important decisions }\end{array}$ & $\begin{array}{l}\text { I'd be able to stay with a high school } \\
\text { acquaintance if traveling to a different city }\end{array}$ \\
\hline $\begin{array}{l}\text { Talking with people online/offline } \\
\text { makes me curious about other } \\
\text { places in the world }\end{array}$ & $\begin{array}{l}\text { When I feel lonely, there are several people } \\
\text { online/offline I can talk to. }\end{array}$ & $\begin{array}{l}\text { I would be willing to contribute money } \\
\text { to MSU after graduation }\end{array}$ & $\begin{array}{l}\text { The people I interact with at MSU } \\
\text { would be good job references for me }\end{array}$ & $\begin{array}{l}\text { I would be able to find information about a } \\
\text { job or internship from a high school } \\
\text { acquaintance }\end{array}$ \\
\hline $\begin{array}{l}\text { Interacting with people } \\
\text { online/offline makes me feel like } \\
\text { part of a larger community }\end{array}$ & $\begin{array}{l}\text { If I needed an emergency loan of } \$ 500, \text { I } \\
\text { know someone online/offline I can turn to. }\end{array}$ & $\begin{array}{l}\text { Interacting with people at MSU makes } \\
\text { me want to try new things }\end{array}$ & $\begin{array}{l}\text { I do not know people at MSU well } \\
\text { enough to get them to do anything } \\
\text { important (reversed) }\end{array}$ & $\begin{array}{l}\text { It would be easy to find people to invite to } \\
\text { my high school reunion }\end{array}$ \\
\hline $\begin{array}{l}\text { Interacting with people } \\
\text { online/offline makes me feel } \\
\text { connected to the bigger picture }\end{array}$ & $\begin{array}{l}\text { The people I interact with online/offline } \\
\text { would put their reputation on the line for me. }\end{array}$ & $\begin{array}{l}\text { Interacting with people at MSU makes } \\
\text { me feel like a part of a larger } \\
\text { community }\end{array}$ & & \\
\hline $\begin{array}{c}\text { Interacting with people } \\
\text { online/offline reminds me that } \\
\text { everyone in the world is connected }\end{array}$ & $\begin{array}{l}\text { The people I interact with online/offline } \\
\text { would be good job references for me. }\end{array}$ & $\begin{array}{l}\text { I am willing to spend time to support } \\
\text { general MSU activities }\end{array}$ & & \\
\hline $\begin{array}{l}\text { I am willing to spend time to } \\
\text { support general online/offline } \\
\text { community activities }\end{array}$ & $\begin{array}{l}\text { The people I interact with online/offline } \\
\text { would share their last dollar with me. }\end{array}$ & $\begin{array}{l}\text { At MSU, I come into contact with new } \\
\text { people all the time }\end{array}$ & & \\
\hline $\begin{array}{l}\text { Interacting with people } \\
\text { online/offline gives me new people } \\
\text { to talk to }\end{array}$ & $\begin{array}{l}\text { I do not know people online/offline well } \\
\text { enough to get them to do anything important. } \\
\text { (reversed) }\end{array}$ & $\begin{array}{l}\text { Interacting with people at MSU } \\
\text { reminds me that everyone in the world } \\
\text { is connected }\end{array}$ & & \\
\hline $\begin{array}{l}\text { Online/Offline, I come in contact } \\
\text { with new people all the time }\end{array}$ & $\begin{array}{l}\text { The people I interact with online/offline } \\
\text { would help me fight an injustice. }\end{array}$ & & & \\
\hline
\end{tabular}


Table 2. Social capital dimensions, subscales and respective measurement items based on Chiu et al. (2006).

\begin{tabular}{|c|c|c|c|}
\hline Social Capital Dimension & Subscale & Measurement Item Number & Measurement Item Statement \\
\hline \multirow{4}{*}{ structural dimension } & \multirow{4}{*}{ social interaction ties } & 1. & \multirow{4}{*}{$\begin{array}{l}\text { I maintain close social relationships with some members in the BlueShop virtual } \\
\text { community. } \\
\text { I spend a lot of time interacting with some members in the BlueShop virtual } \\
\text { community. } \\
\text { I know some members in the BlueShop virtual community on a personal level. } \\
\text { I have frequent communication with some members in the BlueShop virtual } \\
\text { community. }\end{array}$} \\
\hline & & 2. & \\
\hline & & 3. & \\
\hline & & 4 & \\
\hline \multirow{7}{*}{ relational dimension } & \multirow{4}{*}{ trust } & 1. & $\begin{array}{l}\text { Members in the BlueShop virtual community will not take advantage of others even } \\
\text { when the opportunity arises. }\end{array}$ \\
\hline & & 2. & $\begin{array}{c}\text { Members in the BlueShop virtual community will always keep the promises they } \\
\text { make to one another. }\end{array}$ \\
\hline & & 3. & $\begin{array}{c}\text { Members in the BlueShop virtual community would not knowingly do anything to } \\
\text { disrupt the conversation. }\end{array}$ \\
\hline & & $\begin{array}{l}4 . \\
5 .\end{array}$ & $\begin{array}{l}\text { Members in the BlueShop virtual community behave in a consistent manner. } \\
\text { Members in the BlueShop virtual community are truthful in dealing with one another. }\end{array}$ \\
\hline & \multirow[t]{2}{*}{ norm of reciprocity } & 1. & $\begin{array}{l}\text { I know that other members in the BlueShop virtual community will help me, so it is } \\
\text { only fair to help other members. }\end{array}$ \\
\hline & & 2. & I believe that members in the BlueShop virtual community would help me if I need it. \\
\hline & identification & $\begin{array}{l}1 . \\
2 . \\
3 . \\
4 .\end{array}$ & $\begin{array}{l}\text { I feel a sense of belonging towards the BlueShop virtual community. } \\
\text { I have the feeling of togetherness or closeness in the BlueShop virtual community. } \\
\text { I have a strong positive feeling toward the BlueShop virtual community. } \\
\text { I am proud to be a member of the BlueShop community. }\end{array}$ \\
\hline \multirow{6}{*}{ cognitive dimension } & \multirow{3}{*}{ shared language } & 1. & \multirow{3}{*}{$\begin{array}{c}\text { The members in the BlueShop virtual community use common terms or jargons. } \\
\text { Members in the BlueShop virtual community use understandable communication } \\
\text { pattern during the discussion. } \\
\text { Members in the BlueShop virtual community use understandable narrative forms to } \\
\text { post messages or articles. }\end{array}$} \\
\hline & & 2. & \\
\hline & & 3. & \\
\hline & \multirow{3}{*}{ shared vision } & 1. & $\begin{array}{l}\text { Members in the BlueShop virtual community share the vision of helping others solve } \\
\text { their professional problems. }\end{array}$ \\
\hline & & 2. & $\begin{array}{c}\text { Members in the BlueShop virtual community share the same goal of learning from } \\
\text { each other. }\end{array}$ \\
\hline & & 3. & $\begin{array}{c}\text { Members in the BlueShop virtual community share the same value that helping } \\
\text { others is pleasant. }\end{array}$ \\
\hline
\end{tabular}


In the next stage of measurement development, Yli-renko et al. (2001) selected items for the structural and relational dimensions from the existing one by Tsai and Goshal (1998), while developing new items for the cognitive one. In their paper, the structural dimension was termed as social interaction, while the relational one as relationship quality. Furthermore, the cognitive dimension was defined as customer network ties [45]. Wasko and Faraj (2005) proposed a self-rating scale for the cognitive dimension and applied the technique of Tsai and Ghoshal (1998) for the operationalization of the structural dimension. They also defined two subscales for the relational one (i.e., commitment and reciprocity), adapting previously operationalized scales from past literature [46-48]. These approaches were synthesized and validated in the aforementioned study by Chiu et al. (2006), which set a virtual, professional, IT-related community (i.e., BlueShop) in Taiwan as the subject of the analysis [43].

Although previous research indicates that the two previously discussed viewpoints constitute the majority of the empirical measurement approaches in terms of the perceived individual social capital on social media, the paper at hand intends to explore unique, emerging measurement techniques as well, to offer a broad and detailed scope for future studies. The present article aims to scope out the practical characteristics of the empirical studies evaluating social capital constructs on social media, therefore, measuring individual social capital. Based on the previous studies, social capital measurement techniques will be evaluated through a scoping review of 80 published studies to determine the measurement approaches used in past research. Papers employing bridging, bonding, and/or maintained social capital will be explored, followed by those of the multidimensional view, along with a discussion of unique social capital measurement approaches. The goal of the present paper is to: (i) span a broad and detailed scope, (ii) evaluate these techniques, and (iii) identify possible similarities or differences, to provide a more transparent view about the state of this research area and its possible empirical performance and explanatory power.

\section{Search and Filtering Method}

The scoping review methodology $[49,50]$ was applied to map the current state of the scientific knowledge and identify possibly existing research gaps. A scoping review is appropriate here, as it provides an opportunity for a broader research question and the avoidance of bias-assessment.

A multi-keyword search was employed in ProQuest and Google Scholar (i.e., "social capital" AND ("social media" OR "social network" OR "SNS" OR "SM")). The collection of scientific literature followed a funnel approach [51]. Only peer-reviewed articles, peer-reviewed conference proceedings and peer-reviewed book chapters were included into the search criteria. The search process identified 2478 records.

Four manually performed filtering steps were performed on the 2478 records: (a) abstracts and reference lists were checked (139 records remaining), (b) quantitative studies were kept (65 records remaining), (c) studies that did not measure social capital were eliminated (53 records remaining), and (d) the citations of the remaining 53 papers were reviewed backwards and forwards. After the four steps were complete, the final set of $n=80$ records remained.

Additional inclusion criteria for the final set of publications were as follows. The manuscript has to: (a) appear in a peer-reviewed article or conference proceedings or book chapter, (b) be written in the English language, (c) set individual, perceived social capital as the focus, (d) investigate this phenomenon on one or more social media platforms, and (e) empirically measure the perceived social capital in a quantitative manner.

The categorization for comparison and coding were performed using tables in Excel, involving the application of the cultural view, the multidimensional one, or a unique approach. The elements of the operationalized constructs were collected for evaluation based on consistency, joined with the collection of authors, whom the analyzed publications refer to in this regard. Furthermore, the dimension names were collected with attention to papers empirically investigating the multidimensional view of social capital, or using unique measurement approaches. This process involved the authors and two additional, independent reviewers stemming from the respective scientific areas of research. 


\section{Results}

The analysis is based on the observations and trends extracted from the systematically collected literature. As previously indicated, two distinct operationalization techniques emerged from the analyzed $n=80$ records: the majority, (i.e., two thirds $(66 \% ; 53$ items)) of the analyzed publications investigated bridging, bonding, and/or maintained social capital constructs. These studies followed the theoretical considerations of Putnam (2000). The multidimensional view was explored by one-fifth $(18 \% ; 15$ items) of the papers. These two viewpoints represent a contrast in terms of polarity, as they did not intersect regarding their direction of operationalization; however, none of the analyzed articles empirically compared these two concepts.

Bridging social capital was present in all empirical studies that operationalized the social capital constructs according to the cultural view, with the exception of one manuscript. Bonding capital appeared in almost all studies apart from six, thereby indicating its importance. Merely six studies quantified maintained social capital. The description of individual measurement items was explored, based on its cruciality for future replication possibilities. The review concluded that replication was not possible in $18 \%$ (nine items) of the studies interpreting bridging, bonding, and/or maintained social capital measurement on social media, as a lack of a measurement item description.

Through the analysis of individual measurement items, it became evident that there is a considerable diversity in terms of how many, and what kind of items the studies employed. Among the underlying reasons for difference is that the performed principal component analyses (PCA) and confirmatory factor analyses (CFA) delivered different results in individual studies, resulting in the exclusion of at least one or more measurement item. The measurement consistency in the cultural view of social capital was clearly visible in other terms, in the cases of all three measurement constructs (i.e., bridging, bonding, and maintained); however, considerable heterogeneity was found in the operationalization techniques of the multidimensional view.

Table 3 offers a summary of the measurement constructs of each social capital dimension according to the multidimensional view in the 15 analyzed papers, with the exception of Chiu and colleagues (2006).

As Table 3 illustrates, there are distinct differences in terms of sources for measurement operationalization and the construct names for all three dimensions. More specifically, Chiu and colleagues (2006) analyzed the structural dimension by employing one construct (social interaction ties). However, Table 3 shows a variety of construct names (e.g., social networking, instrumental network ties, expressive network ties) in this regard, combined with the diverse operationalization techniques. This trend is visible in terms of the relational and cognitive dimensions as well. It is, however, necessary to note that all studies analyzed in this view offered clear sources in applied measurement, combined with the availability of the measurement items, which can greatly enhance the possibility of replication and the ability of results generalization in a cumulative manner.

The majority of the sampled records employed either the cultural or the multidimensional view of social capital, along with their matching measurement techniques. Unique approaches are summarized in Table 4.

Table 4 reveals a high degree of consistency in the wording for social capital; however, quite distinct differences regarding operationalization techniques are observable as well. While all studies mentioned in Table 4 aimed to analyze the same theoretical concept (i.e., social capital), with a clear majority evaluating bridging, bonding and maintained constructs, the previously mentioned heterogeneity in operationalization discussed in the multidimensional view, extended with these unique approaches, further indicates that there is no particular measurement in this social capital view, which can be considered as common starting point. Quite the contrary, these results address the uncertainty regarding the construct measurement of social capital. Albeit the hypotheses aiming to find relationships with various constructs and social capital itself, were verified in the individual papers, they depicted these results through plentiful operationalization techniques. 
Table 3. Evaluation of the 15 items (19\%) of the final set of publications operationalizing social capital measurement constructs according to the multidimensional view. Abbreviations used: struct. = structural, dim. = dimension, constr. = construct, meas. = measurement(s), rel. = relational, cogn. = cognitive.

\begin{tabular}{|c|c|c|c|c|c|c|c|}
\hline Study & $\begin{array}{c}\text { Struct. Dim. } \\
\text { Constr. Name(s) }\end{array}$ & $\begin{array}{l}\text { Struct. Dim. } \\
\text { Constr. Meas. }\end{array}$ & $\begin{array}{l}\text { Rel. Dim. Constr. } \\
\text { Name(s) }\end{array}$ & $\begin{array}{c}\text { Rel. Dim. } \\
\text { Construct Meas. }\end{array}$ & $\begin{array}{c}\text { Cogn. Dim. } \\
\text { Constr. Name(s) }\end{array}$ & $\begin{array}{l}\text { Cogn. Dim. } \\
\text { Constr. Meas. }\end{array}$ & $\begin{array}{c}\text { Meas. Items } \\
\text { Present in the } \\
\text { Article (yes/no) }\end{array}$ \\
\hline [52] & structural capital & {$[53,54]$} & relational capital & [45] & cognitive capital & {$[53,54]$} & yes \\
\hline$[55]$ & - & - & relational capital & {$[45,53]$} & - & - & yes \\
\hline [56] & social networking & [57] & trust & [58] & shared language & [36] & yes \\
\hline [59] & - & - & trust & [58] & - & - & yes \\
\hline [60] & network ties & [36] & trust & [58] & shared vision & [43] & yes \\
\hline [61] & social interaction & {$[43,45]$} & $\begin{array}{c}\text { trust; } \\
\text { identification; } \\
\text { reciprocity }\end{array}$ & {$[43,48,62]$} & shared language & [43] & yes \\
\hline [63] & - & - & $\begin{array}{l}\text { social capital } \\
\text { identification }\end{array}$ & {$[43,64]$} & - & - & yes \\
\hline [65] & - & - & $\begin{array}{l}\text { social capital } \\
\text { identification }\end{array}$ & {$[43,64]$} & - & - & yes \\
\hline [66] & $\begin{array}{c}\text { instrumental } \\
\text { network ties; } \\
\text { expressive } \\
\text { network ties }\end{array}$ & $\begin{array}{l}\text { own items } \\
\text { developed }\end{array}$ & $\begin{array}{l}\text { identification; } \\
\text { trust in online } \\
\text { community; } \\
\text { norms of } \\
\text { cooperation }\end{array}$ & $\begin{array}{l}\text { own items } \\
\text { developed }\end{array}$ & shared language & [43] & no \\
\hline [67] & social networking & [57] & trust & [58] & shared language & $\begin{array}{l}\text { own items } \\
\text { developed }\end{array}$ & no \\
\hline$[68]$ & - & - & trust & [59] & - & - & yes \\
\hline [69] & $\begin{array}{c}\text { social interaction } \\
\text { ties }\end{array}$ & [43] & trust & [43] & shared vision & [43] & yes \\
\hline [70] & $\begin{array}{c}\text { social interaction } \\
\text { ties }\end{array}$ & [43] & social trust & [57] & shared values & [71] & yes \\
\hline [72] & structural capital & {$[43,57]$} & relational capital & {$[43,57]$} & cognitive capital & {$[43,57]$} & yes \\
\hline
\end{tabular}

Table 4. List and basis of comparison in the cases of 12 publications employing unique measurement approaches.

\begin{tabular}{|c|c|c|}
\hline Study & Name of Social Capital & Measurement of Social Capital \\
\hline [73] & social capital affinity & $\begin{array}{l}5 \text { items partially adapted from the bridging measurement } \\
\text { scales of }[1,27] .\end{array}$ \\
\hline$[74]$ & social capital affinity & $\begin{array}{l}5 \text { items partially adapted from the bridging measurement } \\
\text { scales of }[1,27] .\end{array}$ \\
\hline$[75]$ & social capital & $\begin{array}{l}\text { users' view count on their individual videos and users' } \\
\text { subscriber count on their channel }\end{array}$ \\
\hline [76] & Karma & $\begin{array}{l}\text { measured as the karma rankings of Slashdot users (see [76] } \\
\text { for further details) }\end{array}$ \\
\hline [77] & individual social capital & $\begin{array}{l}\text { measured as the number of readers (equation for social } \\
\text { capital is based on [78]) }\end{array}$ \\
\hline [79] & individual social capital & $\begin{array}{l}\text { 6-item index developed for social life features that represent } \\
\text { effective collective action and pursuing shared objectives in } \\
\text { the participants' communities }\end{array}$ \\
\hline$[80]$ & social capital & $\begin{array}{l}\text { measured as physical (geographical) distance and strength } \\
\text { of friendship (number of comments between two friends) }\end{array}$ \\
\hline [81] & $\begin{array}{l}\text { reciprocal tagging activity } \\
\text { as the formation of } \\
\text { bridging and bonding } \\
\text { social capital }\end{array}$ & $\begin{array}{l}\text { reciprocal actions in the form of liking/commenting a tagging } \\
\text { activity or sharing the specific post the users were tagged in }\end{array}$ \\
\hline
\end{tabular}


Table 4. Cont.

\begin{tabular}{|c|c|c|}
\hline Study & Name of Social Capital & Measurement of Social Capital \\
\hline [82] & social capital & $\begin{array}{l}\text { social capital as the degree of social participation } \\
\text { (connectivity) + social support (content generation } \\
\text { engagement). Connectivity = number of friends, number of } \\
\text { community memberships, number of followers; social } \\
\text { support = number of posts written, number of comments } \\
\text { made, number of comments received }\end{array}$ \\
\hline [83] & social capital & $\begin{array}{l}\text { own measurement developed for civic engagement }(1 \text { item), } \\
\text { interpersonal trust ( } 2 \text { items), political knowledge }(6 \text { items })\end{array}$ \\
\hline [84] & social capital & $\begin{array}{l}\text { life satisfaction = adapted from the Satisfaction with Life } \\
\text { Scale (developed by [85]); social trust = adapted and } \\
\text { modified version of [86]; civic and political participation =a } \\
\text { reduced form of the Index of Civic and Political Engagement } \\
\text { developed by CIRCLE [87] }\end{array}$ \\
\hline [88] & social capital & $\begin{array}{l}\text { political participation }=6 \text { items adapted from the National } \\
\text { Election Studies; civic participation }=5 \text { items developed; } \\
\text { confidence in government }=3 \text { items developed }\end{array}$ \\
\hline
\end{tabular}

\section{Discussion and Conclusions}

The present paper aimed to discover and evaluate prior empirical social capital research conducted in the realm of social media. The primary objective of the study was to tap into measurement operationalization techniques used for evaluating social capital, concentrating on cultural and multidimensional view approaches, and offering an extension into unique measurement approaches. Our analysis involved several tasks to provide a more transparent view about the state of the preceived individual social capital measurement on social media, and its possible empirical performance and explanatory power: (i) span a broad and detailed scope, (ii) evaluate the techniques, and (iii) identify possible similarities or differences. The paper intended to contribute to approaches, such as the meta-analytical approach in Liu et al. (2016), who observed the relationship of bridging and bonding social capital with global social media use and site activity. Such contributions can offer an opportunity of comparison and jointly reveal effect sizes of multiple records to answer the core question, whether the interpreted effects are existing, statistically significant, or the results of selective reporting [77-80].

From the viewpoint of interdisciplinary research, it seems necessary to discuss operationalization technique consistency and offer a synthesis to highlight that the possibility of future meta-analyses is strongly dependent on the comparability and coherence of measurement techniques to maintain validity in effect size measurement and the avoidance of system-inherent bias.

By means of a scoping review, the present study assessed 80 articles to evaluate the standing of social capital research on social media, concentrating on their operationalization techniques. While there is a general observable trend regarding the interpretation of individual measurement items and constructs, studies in the multidimensional view depicted great heterogeneity in terms of operationalization and proposed measurement techniques, which indicates challenging conditions for future meta-analytical approaches in this domain. On the other hand, studies employing the cultural view of social capital, along with the validated measurement techniques proposed by Williams (2006) or Ellison et al. (2007), show a high degree of consistency. It should be noted, however, that there is heterogeneity in the individual studies in terms of employed items from these scales, based on the results of the performed PCA and CFA analyses, resulting in possible item drops. Furthermore, unique social capital measurement techniques on social media are also present in this research domain, enhancing the complexity of a possible, empirical synthesis.

Social media platforms offer to fulfill the human drive to belong and have an exponentially growing user-base. The underlying motivations for the usage of such platforms, along with the 
expected and perceived benefits as a result of being present and active on them, are especially crucial to better understanding human behavior.

The present article aimed to provide a detailed view into the individual, perceived social capital research on social media, and limited itself for the discussion to articles exploring this phenomenon on at least one SM platform. However, as empirical social capital measurement is present in a plethora of further research fields in both an online and offline context, while investigated not merely in a perceived notion, nor solely on an individual level.

Social capital, which seems to be attached to a diverse set of behavioral phenomena [18], can be considered as one of such phenomena; therefore, its analysis, and possible synthesis is an ever pressing issue, since the concept of social capital is indeed a "buzzword" in science [89]. The wide array of measurement approaches discussed in this article, however, raise questions about the measurement: do they measure the same concept, or, as the opposite extreme, maybe none of them do.

The importance of social capital research on social media has possible individual benefits in terms of student learning outcomes, based on the discussed benefits of weak ties as an example. Further benefits include a diverse set of research areas, including the challenge of the cultural barriers for women's economic independence and autonomy [90], highlighting the importance of these investigations aiming to reduce inequalities. This cruciality also manifests itself in labor market studies, wherein individual social capital can be considered as an enabler for successful labor market integration [91]. It also manifests itself in healthcare research, since online conversations can possibly strengthen patient-caregiver connections, leading to successful online health communities, and ultimately, effective policy interventions [92]. Albeit, these examples are far from reaching comprehensivity, they do indicate the relevance of both the existence of social media for the benefits of humanity, and the diversity of areas on which social media can possibly provide benefits for individuals through enabling social capital.

Machine-learning based methods can further enhance the results of such empirical investigations, (e.g., sentiment analysis [93-97]), which could be employed as an extension to reveal the underlying sentiment in student communication present on forums, and class discussion boards. The usage of big data in data sciences, especially in the research area of digital marketing, indicate the crucial importance of such investigations, involving numerous industrial areas, detailed recently by Saura (2020). While companies aim to leverage from such methods, from which the author distinguished nine individual core topics [98], highlighting social media listening as well, the empirical research of individual, perceived social capital might offer crucial insights for corporations aiming to achieve effective digital marketing strategies. This implication is also supported by the relevant publications on the importance of social media marketing, wherein electronic word of mouth (e-WOM) is facilitated by user-generated content, which empowers customers with the ability of sharing their experiences about brands, products, or firms, in which trust plays a key role. [99] Trust is an essential part of the perceived, individual social capital according to the presently discussed views of individual social capital.

It is recommended that future research determines, in detail, how and in what manner, levels of individual online social capital on social media can possibly enable corporational profit enhancements through the mediating role of electronic word of mouth, possibly leading to more refined customer relationship management, accompanied with a positive brand perception.

Author Contributions: Conceptualization, F.P. and C.S.; data curation, F.P.; investigation, F.P.; methodology, F.P.; resources, F.P.; software, F.P.; supervision, C.S.; writing-original draft, F.P.; writing-review \& editing, C.S. All authors have read and agreed to the published version of the manuscript.

Funding: Open Access Funding by the University of Vienna.

Conflicts of Interest: The authors declare no conflict of interest. 


\section{References}

1. Ellison, N.B.; Steinfield, C.; Lampe, C. The benefits of facebook "friends:" Social capital and college students' use of online social network sites. J. Comput. Commun. 2007, 12, 1143-1168. [CrossRef]

2. Boyd, D.M.; Ellison, N.B. Social Network Sites: Definition, History, and Scholarship. J. Comput. Commun. 2007, 13, 210-230. [CrossRef]

3. VanMeter, R.A.; Grisaffe, D.B.; Chonko, L.B. Of "Likes" and "Pins": The Effects of Consumers' Attachment to Social Media. J. Interact. Mark. 2015, 32, 70-88. [CrossRef]

4. Kaplan, A.M.; Haenlein, M. Users of the world, unite! The challenges and opportunities of Social Media. Bus. Horiz. 2010, 53, 59-68. [CrossRef]

5. Jang, J.; Dworkin, J. Does social network site use matter for mothers? Implications for bonding and bridging capital. Comput. Hum. Behav. 2014, 35, 489-495. [CrossRef]

6. Baumeister, R.F.; Leary, M.R. The need to belong: Desire for interpersonal attachments as a fundamental human motivation. Psychol. Bull. 1995, 117, 497-529. [CrossRef]

7. Kim, Y.; Wang, Y.; Oh, J. Digital Media Use and Social Engagement: How Social Media and Smartphone Use Influence Social Activities of College Students. Cyberpsychol. Behav. Soc. Netw. 2016, 19, 264-269. [CrossRef]

8. Maslow, A.H. A Dynamic Theory of Human Motivation. In Understanding Human Motivation; Howard Allen Publishers: Cleveland, OH, USA, 1943; pp. 26-47.

9. Goffman, E. The Presentation of Self in Everyday Life; University of Edinburgh, Social Sciences Research Centre: Edinburgh, UK, 1956.

10. Winter, S.; Neubaum, G.; Eimler, S.C.; Gordon, V.; Theil, J.; Herrmann, J.; Meinert, J.; Krämer, N.C. Another brick in the Facebook wall-How personality traits relate to the content of status updates. Comput. Hum. Behav. 2014, 34, 194-202. [CrossRef]

11. Lin, N. Social Capital: A Theory of Social Structure and Action; Cambridge University Press: London, UK, 2001.

12. Wang, P.; Xie, X.; Wang, X.; Wang, X.; Zhao, F.; Chu, X.; Nie, J.; Lei, L. The need to belong and adolescent authentic self-presentation on SNSs: A moderated mediation model involving FoMO and perceived social support. Pers. Individ. Dif. 2018, 128, 133-138. [CrossRef]

13. Coffé, H.; Geys, B. Toward an empirical characterization of bridging and bonding social capital. Nonprofit Volunt. Sect. Q. 2007, 36, 121-139. [CrossRef]

14. Patulny, R.V.; Lind Haase Svendsen, G. Exploring the social capital grid: Bonding, bridging, qualitative, quantitative. Int. J. Sociol. Soc. Policy 2007, 27, 32-51. [CrossRef]

15. Granovetter, M. The Strength of Weak Ties. Am. J. Sociol. 1973, 78, 1360-1380. [CrossRef]

16. Granovetter, M. The Strength of Weak Ties: A Network Theory Revisited. Sociol. Theory 1983, 1, 201. [CrossRef]

17. Krämer, N.; Rösner, L.; Eimler, S.; Winter, S.; Neubaum, G. Let the Weakest Link Go! Empirical Explorations on the Relative Importance of Weak and Strong Ties on Social Networking Sites. Societies 2014, 4, 785-809. [CrossRef]

18. Fine, B. Theories of Social Capital: Researchers Behaving Badly; Pluto Press: London, UK, 2010.

19. Durlauf, S.N.; Fafchamps, M. Social Capital. In Handbook of Economic Growth; Elsevier Masson SAS: Issy-les-Moulineaux, France, 2005; Volume 1, pp. 1639-1699. ISBN 9780444520432.

20. Johnston, G.; Percy-Smith, J. In search of social capital. Policy Polit. 2003, 31, 321-334. [CrossRef]

21. Knorringa, P.; Van Staveren, I. Beyond social capital: A critical approach. Rev. Soc. Econ. 2007, 65, 1-9. [CrossRef]

22. Portes, A. Social Capital: Its Origins and Applications in Modern Sociology. Annu. Rev. Sociol. 1998, 24, 1-24. [CrossRef]

23. Bourdieu, P. The Forms of Capital. In Handbook of Theory and Research for the Sociology of Education; Richardson, J.G., Ed.; Greenwood Press: New York, NY, USA, 1986.

24. Coleman, J.S. Social Capital in the Creation of Human Captial. Am. J. Sociol. 1988, 94, S95-S120. [CrossRef]

25. Fukuyama, F. Social capital, civil society and development. Third World Q. 2001, 22, 7-20. [CrossRef]

26. Putnam, R.D. Bowling Alone: The Collapse and Revival of American Community; Simon and Schuster: New York, NY, USA, 2000. 
27. Williams, D. On and Off the 'Net: Scales for Social Capital in an Online Era. J. Comput. Commun. 2006, 11, 593-628. [CrossRef]

28. Kraut, R.; Kiesler, S.; Boneva, B.; Cummings, J.; Helgeson, V.; Crawford, A. Internet Paradox Revisited. J. Soc. Issues 2002, 58, 49-74. [CrossRef]

29. Howard, P.E.N.; Rainie, L.; Jones, S. Days and nights on the Internet: The impact of a diffusing technology. Am. Behav. Sci. 2001, 45, 383-404. [CrossRef]

30. Price, V.; Cappella, J.N. Online Deliberation and its Influence: The Electronic Dialogue Project in Campaign 2000. Itsociety 2002, 1, 303-329.

31. Hanifan, L.J. The Rural School Community Center. Ann. Am. Acad. Pol. Soc. Sci. 1916, 67, 130-138. [CrossRef]

32. Hofer, M.; Aubert, V. Perceived bridging and bonding social capital on Twitter: Differentiating between followers and followees. Comput. Hum. Behav. 2013, 29, 2134-2142. [CrossRef]

33. Putnam, R.D.; Goss, K.A. Introduction. In Democracies in Flux: The Evolution of Social Capital in Contemporary Society; Oxford University Press: New York, NY, USA, 2002; pp. 3-21. ISBN 9780195150896.

34. Fine, B. Social Capital Versus Social Theory: Political Economy and Social Science at the turn of the Millennium; Routledge: London, UK, 2001; ISBN1 0415241790. ISBN2 9780415241793. ISBN3 0415241804. ISBN4 9780415241809.

35. Lin, N. Building a Network Theory of Social Capital. In Social Capital Theory and Research; Lin, N., Cook, K., Burt, R.S., Eds.; Transaction Publishers: New Brunswick, NJ, USA, 2001; pp. 3-30.

36. Nahapiet, J.; Ghoshal, S. Social Capital, Intellectual Capital, and the Organizational Advantage. Acad. Manag. Rev. 1998, 23, 242. [CrossRef]

37. Wang, S.; DesRoches, C.T.; Sun, L.; Stennes, B.; Wilson, B.; Cornelis van Kooten, G. Linking forests and economic well-being: A four-quadrant approach. Can. J. For. Res. 2007, 37, 1821-1831. [CrossRef]

38. Hunter, M.L. "If You're Light You're Alright"—Light Skin Color as Social Capital for Women of Color. Gend. Soc. 2002, 16, 175-193. [CrossRef]

39. Wood, L.; Giles-Corti, B.; Bulsara, M. The pet connection: Pets as a conduit for social capital? Soc. Sci. Med. 2005, 61, 1159-1173. [CrossRef] [PubMed]

40. Domahidi, E. The Associations Between Online Media Use and Users' Perceived Social Resources: A Meta-Analysis. J. Comput. Commun. 2018, 23, 181-200. [CrossRef]

41. Liu, D.; Ainsworth, S.E.; Baumeister, R.F. A meta-analysis of social networking online and social capital. Rev. Gen. Psychol. 2016, 20, 369-391. [CrossRef]

42. Quan-Haase, A.; Wellman, B. How does the Internet affect social capital? In Social Capital and Information Technology; Huysman, M., Wulf, V., Eds.; MIT Press: Cambridge, MA, USA, 2004; pp. 113-132.

43. Chiu, C.M.; Hsu, M.H.; Wang, E.T.G. Understanding knowledge sharing in virtual communities: An integration of social capital and social cognitive theories. Decis. Support Syst. 2006, 42, 1872-1888. [CrossRef]

44. Tsai, W.; Ghoshal, S. Social Capital and Value Creation: The Role of Intrafirm Networks. Acad. Manag. J. 1998, 41, 464-476. [CrossRef]

45. Yli-Renko, H.; Autio, E.; Sapienza, H.J. Social capital, knowledge acquisition, and knowledge exploitation in young technology-based firms. Strateg. Manag. J. 2001, 22, 587-613. [CrossRef]

46. Constant, D.; Sproull, L.; Kiesler, S. The Kindness of Strangers: The Usefulness of Electronic Weak Ties for Technical Advice. Organ. Sci. 1996, 7, 119-135. [CrossRef]

47. Mowday, R.T.; Steers, R.M.; Porter, L.W. The measurement of organizational commitment. J. Vocat. Behav. 1979, 14, 224-247. [CrossRef]

48. McLure Wasko, M.; Faraj, S. Why Should I Share? Examining Social Capital and Knowledge Contribution in Electronic Networks of Practice Why Should I Share? Examining Social Capital and Knowledge Contribution in electronic networks of practice1. Source MIS Q. 2005, 29, 35-57. [CrossRef]

49. Arksey, H.; O’Malley, L. Scoping studies: Towards a methodological framework. Int. J. Soc. Res. Methodol. 2005, 8, 19-32. [CrossRef]

50. Levac, D.; Colquhoun, H.; O’Brien, K.K. Scoping studies: Advancing the methodology. Implement. Sci. 2010, 5, 69. [CrossRef] 
51. Webster, J.; Watson, R.T. Analyzing the Past to Prepare for the Future: Writing a Literature Review. MIS Q. 2002, 26, xiii-xxiii.

52. Bharati, P.; Zhang, W.; Chaudhury, A. Better knowledge with social media? Exploring the roles of social capital and organizational knowledge management. J. Knowl. Manag. 2015, 19, 456-475. [CrossRef]

53. Leana, C.R.; Pil, F.K. Social Capital and Organizational Performance: Evidence from Urban Public Schools. Organ. Sci. 2006, 17, 353-366. [CrossRef]

54. Teo; Wei; Benbasat Predicting Intention to Adopt Interorganizational Linkages: An Institutional Perspective. MIS Q. 2003, 27, 19. [CrossRef]

55. Bharati, P.; Chaudhury, A. Assimilation of Big Data Innovation: Investigating the Roles of IT, Social Media, and Relational Capital. Inf. Syst. Front. 2018, 21, 1357-1368. [CrossRef]

56. Cao, X.; Guo, X.; Liu, H.; Gu, J. The role of social media in supporting knowledge integration: A social capital analysis. Inf. Syst. Front. 2015, 17, 351-362. [CrossRef]

57. Chow, W.S.; Chan, L.S. Social network, social trust and shared goals in organizational knowledge sharing. Inf. Manag. 2008, 45, 458-465. [CrossRef]

58. Levin, D.Z.; Cross, R. The Strength of Weak Ties You Can Trust: The Mediating Role of Trust in Effective Knowledge Transfer. Manag. Sci. 2004, 50, 1477-1490. [CrossRef]

59. Cao, X.; Guo, X.; Vogel, D.R.; Liu, H.; Gu, J. Understanding the influence of social media in the workplace: An integration of media synchronicity and social capital theories. In Proceedings of the Annual Hawaii International Conference on System Sciences, Maui, HI, USA, 4-7 January 2012; pp. 3938-3947.

60. Cao, X.; Guo, X.; Vogel, D.; Zhang, X. Exploring the influence of social media on employee work performance. Internet Res. 2016, 26, 529-545. [CrossRef]

61. Chang, H.H.; Chuang, S.S. Social capital and individual motivations on knowledge sharing: Participant involvement as a moderator. Inf. Manag. 2011, 48, 9-18. [CrossRef]

62. Ridings, C.M.; Gefen, D.; Arinze, B. Some antecedents and effects of trust in virtual communities. J. Strateg. Inf. Syst. 2002, 11, 271-295. [CrossRef]

63. Huang, R.; Kim, H.J.; Kim, J. Social capital in QQ China: Impacts on virtual engagement of information seeking, interaction sharing, knowledge creating, and purchasing intention. J. Mark. Manag. 2013, 29, 292-316. [CrossRef]

64. Dholakia, U.M.; Bagozzi, R.P.; Pearo, L.K. A social influence model of consumer participation in networkand small-group-based virtual communities. Int. J. Res. Mark. 2004, 21, 241-263. [CrossRef]

65. Kim, H.; Kim, J.; Huang, R. Social Capital in the Chinese Virtual Community: Impacts on the Social Shopping Model for Social Media. Glob. Econ. Rev. 2014, 43, 3-24. [CrossRef]

66. Law, S.P.-M.; Chang, M.K. Fostering Knowledge Exchange in Online Communities: A Social Capital Building Approach. In Proceedings of the ICIS 2008, Paris, France, 14-17 December 2008; pp. 1-22.

67. Mei, Y. Contribution of Social Media Use at Work to Social Capital and Knowledge Sharing: A Comparison between Chinese and Thai Employees. Int. J. Appl. Comput. Technol. Inf. Syst. 2016, 6, 21-27.

68. Offong, G.O.; Costello, J. Enterprise social media impact on human resource practices. Evid. Based HRM A Glob. Forum Empir. Scholarsh. 2017, 5, 328-343. [CrossRef]

69. Okazaki, S.; Andreu, L.; Campo, S. Knowledge Sharing Among Tourists via Social Media: A Comparison Between Facebook and TripAdvisor. Int. J. Tour. Res. 2017, 19, 107-119. [CrossRef]

70. Son, J.E.; Lee, S.H.; Cho, E.Y.; Kim, H.W. Examining online citizenship behaviours in social network sites: A social capital perspective. Behav. Inf. Technol. 2016, 35, 730-747. [CrossRef]

71. Zhao, L.; Lu, Y. Enhancing perceived interactivity through network externalities: An empirical study on micro-blogging service satisfaction and continuance intention. Decis. Support Syst. 2012, 53, 825-834. [CrossRef]

72. Wu, Y.-L.; Li, E.Y.; Chang, W.-L. Nurturing user creative performance in social media networks. Internet Res. 2016, 26, 869-900. [CrossRef]

73. Barker, V.; Dozier, D.M.; Weiss, A.S.; Borden, D.L. Facebook "friends": Effects of social networking site intensity, social capital affinity, and flow on reported knowledge-gain. J. Soc. Media Soc. 2013, 2, 76-97. 
74. Barker, V.; Dozier, D.M.; Weiss, A.S.; Borden, D.L. Harnessing peer potency: Predicting positive outcomes from social capital affinity and online engagement with participatory websites. New Media Soc. 2015, 17, 1603-1623. [CrossRef]

75. Feroz Khan, G.; Vong, S. Virality over YouTube: An empirical analysis. Internet Res. 2014, 24, 629-647. [CrossRef]

76. Ganley, D.; Lampe, C. The ties that bind: Social network principles in online communities. Decis. Support Syst. 2009, 47, 266-274. [CrossRef]

77. Gaudeul, A.; Giannetti, C. The role of reciprocation in social network formation, with an application to LiveJournal. Soc. Netw. 2013, 35, 317-330. [CrossRef]

78. Glaeser, E.; Laibson, D.; Sacerdote, B. An Economic Approach to Social Capital. Econ. J. 2002, 112, F437-F458. [CrossRef]

79. Gil de Zúñiga, H.; Jung, N.; Valenzuela, S. Social Media Use for News and Individuals' Social Capital, Civic Engagement and Political Participation. J. Comput. Commun. 2012, 17, 319-336. [CrossRef]

80. Gilbert, E.; Karahalios, K.; Sandvig, C. The network in the garden: Designing social media for rural life. Am. Behav. Sci. 2010, 53, 1367-1388. [CrossRef]

81. Ha, T.; Han, S.; Lee, S.; Kim, J.H. Reciprocal nature of social capital in Facebook: An analysis of tagging activity. Online Inf. Rev. 2017, 41, 826-839. [CrossRef]

82. Nguyen, T.; Dao, B.; Phung, D.; Venkatesh, S.; Berk, M. Online Social Capital: Mood, Topical and Psycholinguistic Analysis. In Proceedings of the 7th AAAI International Conference on Weblogs and Social Media, Cambridge, MA, USA, 8-11 July 2013; pp. 449-456.

83. Pasek, J.; More, E.; Romer, D. Realizing the social internet? Online social networking meets offline civic engagement. J. Inf. Technol. Polit. 2009, 6, 197-215. [CrossRef]

84. Valenzuela, S.; Park, N.; Kee, K.F. Is There social capital in a social network site?: Facebook use and college student's life satisfaction, trust, and participation1. J. Comput. Commun. 2009, 14, 875-901. [CrossRef]

85. Diener, E.; Emmons, R.A.; Larsen, R.J.; Griffin, S. The Satisfaction with Life Scale. J. Pers. Assess. 1985, 49, 71-75. [CrossRef]

86. Rosenberg, M. Misanthropy and Political Ideology. Am. Sociol. Rev. 1956, 21, 690-695. [CrossRef]

87. Andolina, M.; Keeter, S.; Zukin, C.; Jenkins, K. A Guide to the Index of Civic and Political Engagement. Available online: https://www.researchgate.net/publication/267399505_A_guide_to_the_index_of_civic_and_ political_engagement (accessed on 3 November 2020).

88. Zhang, W.; Johnson, T.J.; Seltzer, T.; Bichard, S.L. The revolution will be networked: The influence of social networking sites on political attitudes and behavior. Soc. Sci. Comput. Rev. 2010, 28, 75-92. [CrossRef]

89. Solow, R.M. But Verify. New Repub. 1995, 213, 36-39.

90. Ali Aksar, I.; Danaee, M.; Maqsood, H.; Firdaus, A. Women's social media needs and online social capital: Bonding and bridging social capital in Pakistan. J. Hum. Behav. Soc. Environ. 2020, 00, 1-24. [CrossRef]

91. Gericke, D.; Burmeister, A.; Löwe, J.; Deller, J.; Pundt, L. How do refugees use their social capital for successful labor market integration? An exploratory analysis in Germany. J. Vocat. Behav. 2018, 105, 46-61. [CrossRef]

92. Panzarasa, P.; Griffiths, C.J.; Sastry, N.; de Simoni, A. Social medical capital: How patients and caregivers can benefit from online social interactions. J. Med. Internet Res. 2020, 22, 1-4. [CrossRef]

93. Poecze, F.; Ebster, C.; Strauss, C. Social media metrics and sentiment analysis to evaluate the effectiveness of social media posts. Procedia Comput. Sci. 2018, 130, 660-666. [CrossRef]

94. Poecze, F.; Ebster, C.; Strauss, C. Let's play on Facebook: Using sentiment analysis and social media metrics to measure the success of YouTube gamers' post types. Pers. Ubiquitous Comput. 2019. [CrossRef]

95. Hew, K.F.; Hu, X.; Qiao, C.; Tang, Y. What predicts student satisfaction with MOOCs: A gradient boosting trees supervised machine learning and sentiment analysis approach. Comput. Educ. 2020, 145, 103724. [CrossRef]

96. Troisi, O.; Grimaldi, M.; Loia, F.; Maione, G. Big data and sentiment analysis to highlight decision behaviours: A case study for student population. Behav. Inf. Technol. 2018, 37, 1111-1128. [CrossRef]

97. Kumar, A.; Jain, R. Sentiment analysis and Feedback Evaluation. In Proceedings of the 2015 IEEE 3rd International Conference on MOOCs, Innovation and Technology in Education (MITE), Amritsar, India, 1-2 October 2015; pp. 433-436. 
98. Saura, J.R. Using Data Sciences in Digital Marketing: Framework, methods, and performance metrics. J. Innov. Knowl. 2020. [CrossRef]

99. Alalwan, A.A.; Rana, N.P.; Dwivedi, Y.K.; Algharabat, R. Social media in marketing: A review and analysis of the existing literature. Telemat. Inform. 2017, 34, 1177-1190. [CrossRef]

Publisher's Note: MDPI stays neutral with regard to jurisdictional claims in published maps and institutional affiliations.

(C) 2020 by the authors. Licensee MDPI, Basel, Switzerland. This article is an open access article distributed under the terms and conditions of the Creative Commons Attribution (CC BY) license (http://creativecommons.org/licenses/by/4.0/). 